IJIS Indonesian Journal on Information System

\title{
SISTEM INFORMASI DATA BARANG INVENTARIS BERBASIS WEB PADA KEJAKSAAN NEGERI TERNATE
}

\section{INFORMATION SYSTEM OF INVENTORY GOODS WEB-BASED ON THE STATE PROSECUTOR TERNATE}

\author{
Syukri Ali ${ }^{1}$, Arisandy Ambarita ${ }^{2}$ \\ Program Studi Manajemen Informatika, \\ Politeknik Sains dan Teknologi Wiratama Maluku Utara \\ syukriali03@gmail.com
}

\begin{abstract}
Abstrak
Kejaksaan Negeri Ternate merupakan suatu lembaga pemerintah di kota ternate yang bergerak di bidang hukum. Dimana sistem yang digunakan pada pengelolaan data barang invetaris masih bersifat konvesional, dimana pada pengiputan data-data barang invetaris masih dilakukan pada kertas dan media penyimpanan data disimpan pada arsip. Untuk menunjang kinerja para pegawai kejaksaan, maka diperlukan adanya sistem yang terkomputerisasi sebagai sarana untuk keperluan para pegawai dilingkup Kejaksaan dalam melakukan aktifitasnya Dengan melihat pada perkembangan teknologi informasi, dan tuntutan para pegawai di lingkup Kejaksaan yang semakin kompleks, maka pengembangan dan pemanfaatan teknologi informasi sangat penting. Oleh karena itu, pendataan barang inventaris kantor berbasis web sangat diperlukan dalam menunjang kinerja para pegawainya dan administrasi pelaporan pada Kejaksaan Negeri Ternate. Peniltian ini dilakukan pada Kejaksaan Negeri Ternate bertujuan untuk merancang sistem informasi data barang invetaris. pengumpulan data diperoleh melalui observasi, wawancara, Analisis, Perancangan dan Implementasi, Sistem yang di rancang diharapkan dapat menerapkan Sistem untuk mempermudah pegawai dalam mengelola barang invetaris yang ada pada Kejaksaan Negeri ternate
\end{abstract}

\section{Kata Kunci : Sistem Informasi, Barang Invetaris, Web}

\begin{abstract}
Ternate is a State Government agency in the town of ternate in the law. Where systems are used in the management of the data items are still accounting for inventory, wherein input inventory stuff data is still done on paper and storage media data is stored on the archive. To support the performance of the prosecutor's staff, it is necessary to have a computerized system as a means for the needs of employees in the scope of the Attorney in doing its activities with respect to the development of information technology, and the demands of the employees in the scope of the Prosecutor's Office that is increasingly complex, then the development and utilization of information technology is crucial. Therefore, logging inventory web-based Office is indispensable in performance to support its officers and State Attorney's reporting on the administration of Ternate. This is done at the Research on the State Prosecutor Ternate aims to design a data information system of goods inventory. the collection of data obtained through observation, interviews, analysis, design, and implementation, systems in engineering are expected to implement a System to facilitate employees in managing goods inventory on the State Prosecutor of ternate
\end{abstract}

Keywords: Information Systems, Inventory, Web 


\section{PENDAHULUAN}

Sistem informasi yang mendukung membuat kinerja suatu instansi akan terlaksana dengan baik dan dapat menangani berbagai pengolahan data dengan menggunakan teknologi informasi. Sistem informasi di buat untuk mempermudah dalam pengelolaan dan penepatan penyimpanan data maka dapat menghasilkan suatu informasi yang tepat dan akurat. Adanya sistem informasi yang tepat dan akurat dapat mengurangi terjadinya kesalahan yang tidak diinginkan sehinga dapat meningkatkan kinerja yang lebih efesien dan kecepatan operasional pada suatu instansi.

Kejaksaan Negeri Ternate merupakan suatu lembaga pemerintah di kota ternate yang bergerak di bidang hukum. Dimana sistem yang digunakan pada pengelolaan data barang invetaris masih bersifat konvesional, dimana pada pengiputan data-data barang invetaris masih dilakukan pada kertas dan media penyimpanan data disimpan pada arsip. Untuk menunjang kinerja para pegawai kejaksaan, maka diperlukan adanya sistem yang terkomputerisasi sebagai sarana untuk keperluan para pegawai dilingkup Kejaksaan dalam melakukan aktifitasnya

Dengan melihat pada perkembangan teknologi informasi, dan tuntutan para pegawai di lingkup Kejaksaan yang semakin kompleks, maka pengembangan dan pemanfaatan teknologi informasi sangat penting. Oleh karena itu, pendataan barang inventaris kantor berbasis web sangat diperlukan. Dalam menunjang kinerja para pegawainya dan administrasi pelaporan pada Kejaksaan Negeri Ternate

\section{Rumusan Masalah}

Berdasarkan latar belakang di atas, maka masalah dalam penelitian ini di rumuskan sebagai berikut: Bagaimana merancang sistem informasi data barang inventaris Kantor pada Kejaksaan Negeri Ternate? penelitian ini dibatasi pada bagian data yang berhubungan dengan pembelian barang inventaris kantor, dengan adanya sistem informasi data barang Inventaris Kantor ini diharapkan dapat memberikan kemudahan, dalam mengetahui informasi tentang data barang inventaris kantor dalam mendukung kinerja dan pelayanan pada Kejaksaan Negeri Ternate.

\section{LANDASAN TEORI \\ Defenisi Sistem}

Sistem pada umumnya kumpulan dari sub-sub sistem yang saling berinteraksi antara sub sistem yang satu dengan sub sistem yang lain dalam mencapai tujuan yang sama. Dewasa ini ada dua pendekatan yang digunakan dalam mengartikan sistem yaitu kelompok yang lebih menekankan pada prosedurnya dan kelompok yang menekankan pada komponen-komponen atau elemennya (Jogianto, 2005:101).

Sistem menurut Al Fatta, Hanif, (2007:3) yaitu kumpulan atau himpunan dari unsur atau variabel-variabel yang saling terorganisasi, saling berinteraksi, dan saling bergantung sama lain

\section{Definisi Informasi}

Kusrini (2007) dalam Taufik (2013:15) mendefinisikan bahwa informasi merupakan hasil olahan data, di mana data tersebut sudah diproses dan diinterprestasikan menjadi sesuatu yang bermakna untuk pengambilan keputusan. Informasi juga diartikan sebagai himpunan dari data yang relevan dengan satu atau beberapa orang dalam suatu waktu. Sedangkan Mulyadi (2001:50) menyatakan 
bahwa informasi adalah suatu elemen dan sumber daya yang sangat penting dan berharga bagi suatu perusahaan, disamping sumber daya yang lain yaitu uang, manusia, materi dan mesin. Informasi adalah data yang sudah diolah menjadi suatu bentuk sehingga lebihberguna bagi si penerima dan nilai tersebut dapat digunakan untuk pengambilan keputusan.

\section{Definisi Barang Investaris Kantor}

Investarisasi merupakan proses pengelola pengadaan atau persedian barang yang dimiliki oleh suatu kantor atau perusahan dalam melakukan kegiatan operasional. Tanpa adanya inventori suatu kegiatan usaha tidak akan terlaksana, untuk itu keberadaan inventori sangat penting.

Inventaris kantor sangatlah penting bagi kelangsungan sebuah instansi. Apabila salah satu atau beberapa perlengkapan mengalami gangguan, maka pasti akan menghambat jalannya roda perekonomian perusahan yang biasanya berupa tidak teraturnya keorganisasian sebuah inventaris kantor atau kurangnya sebuah sistem dalam menginventaris perlengkapan kantor Wahana, (2007 : 37).

\section{Defenisi Web}

World Wide Web atau WWW atau juga dikenal dengan WEB adalah salah satu layanan yang didapat oleh pemakai komputer yang terhubung ke internet. Web ini menyediakan informasi bagi pemakai komputer yang terhubung ke internet dari sekedar informasi "sampah" atau informasi yang tidak berguna sama sekali sampai informasi yang serius; dari informasi yang gratisan sampai informasi yang komersial. Website atau situs dapat diartikan sebagai kumpulan halaman-

halaman yang digunakan untuk

menampilkan informasi teks, gambar diam atau gerak, animasi, suara, dana atau gabungan dari semua yaitu baik yang bersifat statis maupun dinamis yang membentuk satu rangkaian bangunan yang saling terkait dimana masing-masing dihubungkan dengan jaringan-jaringan halaman (hyperlink).

\section{Definisi HTML}

Budi Rahajoet, dkk (2011:286) didalam buku Modul Pemrograman Web (HTML, PHP \& MySQL) menjelaskan bahwa HTML adalah singkatan dari HyperText Markup Language. HTML merupakan file teks yang ditulis menggunakan aturan-aturan kode tertentu untuk kemudian disajikan ke user melalui suatu aplikasi web browser.

Dapat disimpulkan bahwa HTML (HyperText Markup Language) ialah bahasa pemrograman untuk membuat desain body atau layout (tampilan) dari sebuah website. Bahasa pemrograman HTML inilah yang akan dieksekusi oleh browser dan ditampilkan dijendela browser.

\section{Definisi Database}

Wahana Komputer (2010). Database (Basis Data) merupakan kumpulan data yang saling berhubungan satu dengan yang lainnya, tersimpan di simpanan luar komputer dan digunakan perangkat lunak tertentu untuk memanipulasinya.

Database merupakan salah satu komponen yang penting di sistem informasi, karena berfungsi sebagai basis penyedia informasi bagi para pemakainya.

\section{Definisi MySQL}

Wahana Komputer (2010). MySQL adalah sebuah implementasi dari sistem manajemen basisdata relasional 
(RDBMS) yang didistribusikan secara gratis. Setiap pengguna dapat secara bebas menggunakan MySQL, namun dengan batasan perangkat lunak tersebut tidak boleh dijadikan produk turunan yang bersifat komersial. MySQL sebenarnya merupakan turunan salah satu konsep utama dalam basisdata yang telah ada sebelumnya; SQL (Structured Query Language). SQL adalah sebuah konsep pengoperasian basisdata, terutama untuk pemilihan atau seleksi dan pemasukan data, yang memungkinkan pengoperasian data dikerjakan dengan mudah secara otomatis.

\section{Definisi PHP}

Agus Saputra (2011:1) PHP atau yang memiliki kepanjangan PHP Hypertext Preprocessor merupakan suatu bahasa pemrograman yang difungsikan untuk membangun suatu website dinamis. PHP berjalan pada sisi server sehingga PHP disebut juga sebagai bahasa Server Side Scripting. Artinya bahwa dalam setiap/untuk menjalankan PHP wajib adanya seb server.

\section{Definisi CSS}

Kurniawan (2008:1) dalam buku yang berjudul desain web praktis dengan CSS menjelaskan bahwa CSS atau Cascading Style Sheets adalah sebuah dokumen yang berisi aturan yang digunakan untuk memisahkan isi dengan layout dalam halaman-halaman web yang dibuat.CSS memperkenalkan "template" yang berupa style untuk dibuat dalam mengizinkan penulisan kode yang lebih mudah dari halaman-halaman web yang dirancang.

\section{Definisi Xampp}

Bunafit Nugroho

(2008:75) mengatakan bahwa XAMPP merupakan paket PHP yang berbasis Open Source yang dikembangkan oleh sebuah komunitas Open Source. Dengan menggunakan XAMPP tidak perlu lagi bingung untuk melakukan penginstalan program-program yang lain, karena semua kebutuhan telah disediakan oleh XAMPP

\section{METODE PENELITIAN}

\section{Teknik Pengumpulan Data}

Metode pengumpulan data antara lain :

1. Wawancara. Metode yang dilakukan dengan cara tanya jawab langsung tentang system informasi data barang inventaris kantor, terhadap pihakpihak yang bersangkutan dalam hal ini Kejaksaan Negeri Ternate.

2. Observasi (Pengamatan). Metode pengumpulan data dengan cara terjun lansung ke lapangan agar informasi yang diperoleh benar-benar akurat

\section{Bahan dan Alat Penelitian}

Software

1. System operasi windows 7 ultimate

2. Notepad ++

3. Web server XAMPP (Apache, MySQL)

4. Bahasa pemrograman HTML, PHP, $S Q L$ dan $C S S$

Hardware

1. Processor Intel Core i3 2328M (2.2GHz, 3MB L3 cache)

2. Intel HD Graphics 3000

3. LCD LED HD 14.0"

4. Mainboard Intel.

5. RAM 2 GB DDR3.

6. Harddisk $500 \mathrm{~GB}$.

7. Mouse Optik

8. Keyboard

9. Printer Canon IP2700.

Analisa sistem yang berjalan 
Analisa sistem yang berjalan merupakan model tampilan yang sudah diindentifikasi pada masalah yang di hadapi pada Kejaksaan Negeri Ternate, Sistem yang berjalan pada Kejaksaan Negeri Ternate masih menggunakan sistem yang belum terkomputerisasi. Mulai pengelolaan data invetaris barang, dan proses penyimpanan yang masih disimpan pada arsip, berikut merupakan tampilan desain analisa sistem yang berjalan disajikan dalam gambar sebgai berikut:

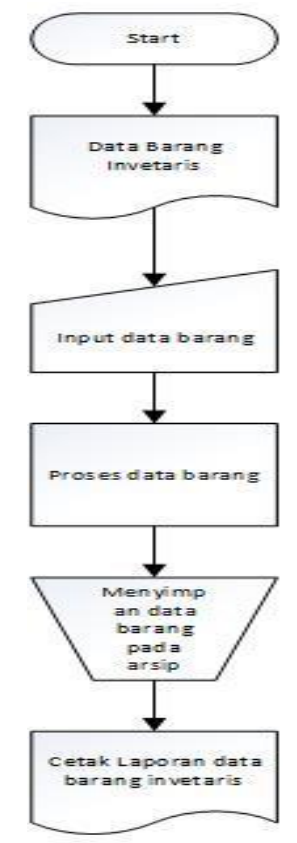

Gambar 1 : Flowchart Sistem Yang Berjalan

\section{Rancangan system yang di usulkan}

Rancangan sistem merupakan desain sistem yang baru untuk digunakan menggatikan sistem yang lama di Kejaksaan Negeri Ternate. Berikut merupakan tampilan rancangan sistem yang baru di sajikan sebagai berikut:

\section{Gambar 2 : Flowchart Sistem Yang Diusulkan}

\section{PERANCANGAN SISTEM Diagram Konteks}

Context Diagram merupakan kejadian dari suatu alur/alir data. Dimana satu lingkaran mempresentasikan seluruh sistem dan merupakan tingkatan tertinggi dalam diagram aliran data dan hanya memuat satu proses dan menunjukkan sistem secara keseluruhan

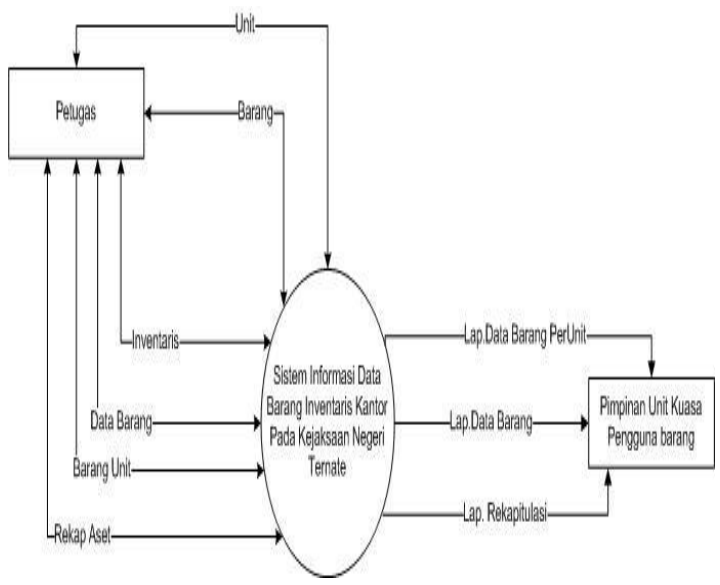

Gambar 3 : Diagram Konteks

\section{DFD Level 1}

Data Flow Diagram (DFD) adalah representasi grafik dari sebuah sistem. DFD menggambarkan komponenkomponen sebuah sistem, aliran-aliran data di mana komponen-komponen tersebut, dan asal, tujuan, dan 
penyimpanan dari data tersebut. Berikut adalah tampilan DFD Level 1 dari Perancangan Sistem Informasi Data Barang Inventaris Kantor Pada Kejaksaan Negeri Ternate disajikan dalam gamabr sebagai berikut:

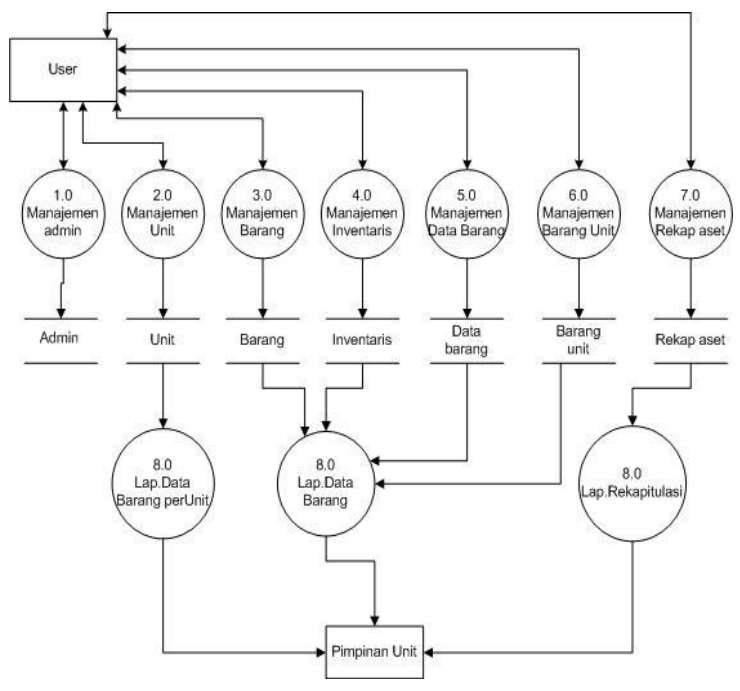

Gambar 4 : DFD Level 1

\section{ERD (entity relationship diagram)}

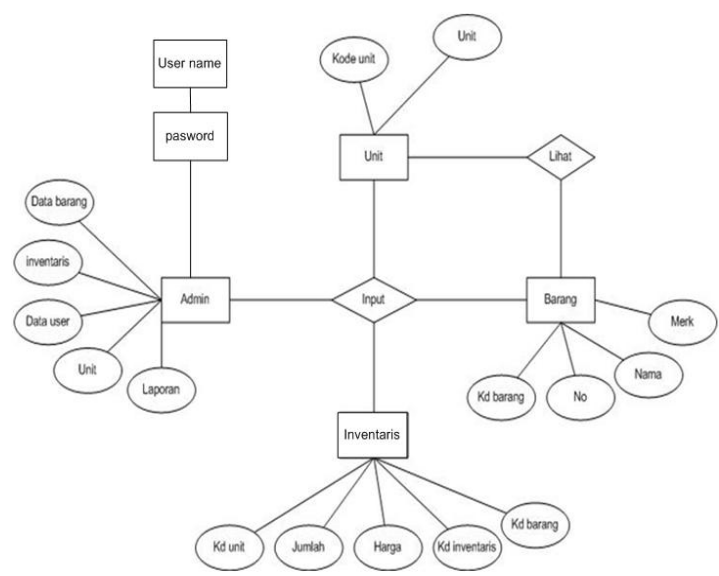

Gambar 5:Entity Relationship Diagram

\section{Relasi Tabel}

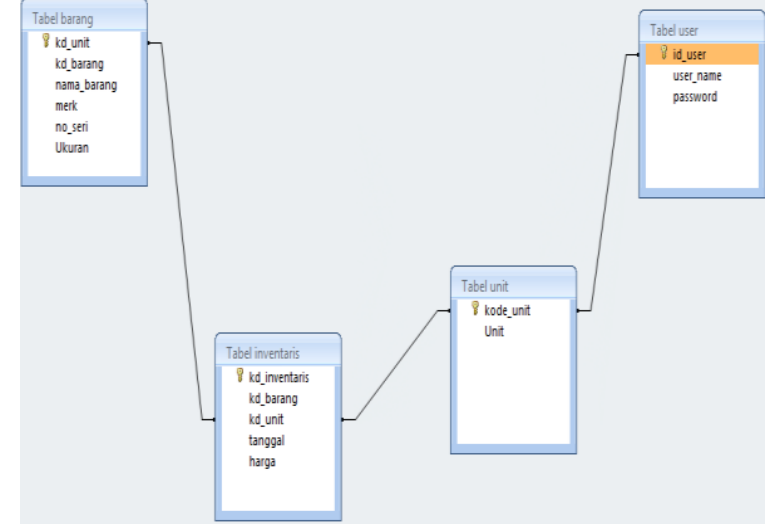

Gambar 6:Relasi Tabel Sistem

Perancangan Tabel

Tabel Unit

Tabel 1 : Unit

\begin{tabular}{|c|c|c|c|c|}
\hline $\begin{array}{c}\text { N } \\
\text { o }\end{array}$ & $\begin{array}{c}\text { Field } \\
\text { Name }\end{array}$ & Type & Size & $\begin{array}{c}\text { Keteranga } \\
\mathbf{n}\end{array}$ \\
\hline 1 & $\begin{array}{c}\text { Kd_Un } \\
\text { it }\end{array}$ & $\begin{array}{c}\text { Varcha } \\
\text { r }\end{array}$ & 8 & $\begin{array}{c}\text { Kode unit } \\
\text { (PK) }\end{array}$ \\
\hline 2 & Unit & $\begin{array}{c}\text { Varcha } \\
\text { r }\end{array}$ & 2 & nama unit \\
& & 5 & \\
\hline
\end{tabular}

Tabel Barang

Tabel 2 : Barang

\begin{tabular}{|c|l|c|c|l|}
\hline $\begin{array}{c}\text { N } \\
\text { o }\end{array}$ & \multicolumn{1}{|c|}{$\begin{array}{c}\text { Field } \\
\text { Name }\end{array}$} & Type & $\begin{array}{c}\text { Siz } \\
\text { e }\end{array}$ & $\begin{array}{l}\text { Keteranga } \\
\mathbf{n}\end{array}$ \\
\hline 1 & Kd_Unit & $\begin{array}{c}\text { Varcha } \\
\text { r }\end{array}$ & 8 & $\begin{array}{l}\text { Kode Unit } \\
\text { (FK) }\end{array}$ \\
\hline 2 & Kd_Barang & $\begin{array}{c}\text { Varcha } \\
\text { r }\end{array}$ & 8 & $\begin{array}{l}\text { Kode } \\
\text { Barang } \\
\text { (PK) }\end{array}$ \\
\hline 3 & $\begin{array}{l}\text { NamaBaran } \\
\text { g }\end{array}$ & $\begin{array}{c}\text { Varcha } \\
\text { r }\end{array}$ & 25 & $\begin{array}{l}\text { Nama } \\
\text { Barang }\end{array}$ \\
\hline 4 & Merk & $\begin{array}{c}\text { Varcha } \\
\text { r }\end{array}$ & 25 & $\begin{array}{l}\text { Merek } \\
\text { Barang }\end{array}$ \\
\hline 5 & NoSeri & $\begin{array}{c}\text { Varcha } \\
\text { r }\end{array}$ & 10 & $\begin{array}{l}\text { No Seri } \\
\text { Barang }\end{array}$ \\
\hline 6 & Ukuran & $\begin{array}{c}\text { Varcha } \\
\text { r }\end{array}$ & 10 & $\begin{array}{l}\text { Ukuran } \\
\text { Barang }\end{array}$ \\
\hline
\end{tabular}

Tabel Inventaris

Tabel 3 : Inventaris

\begin{tabular}{|c|c|c|c|l|}
\hline $\begin{array}{c}\text { N } \\
\text { o }\end{array}$ & \multicolumn{1}{|c|}{$\begin{array}{c}\text { Field } \\
\text { Name }\end{array}$} & Type & $\begin{array}{c}\text { Siz } \\
\text { e }\end{array}$ & $\begin{array}{l}\text { Keteranga } \\
\mathbf{n}\end{array}$ \\
\hline 1 & $\begin{array}{l}\text { KdInventar } \\
\text { is }\end{array}$ & $\begin{array}{c}\text { Varcha } \\
\mathrm{r}\end{array}$ & 10 & $\begin{array}{l}\text { Kode } \\
\text { Inventaris } \\
(\mathrm{PK})\end{array}$ \\
\hline
\end{tabular}




\begin{tabular}{|c|l|c|c|l|}
\hline 2 & Kd_Barang & $\begin{array}{c}\text { Varcha } \\
\mathrm{r}\end{array}$ & 8 & $\begin{array}{l}\text { Kode } \\
\text { Barang } \\
(\text { FK) }\end{array}$ \\
\hline 3 & Kd_Unit & $\begin{array}{c}\text { Varcha } \\
\mathrm{r}\end{array}$ & 8 & $\begin{array}{l}\text { Kode Unit } \\
\text { (FK) }\end{array}$ \\
\hline 4 & Tanggal & $\begin{array}{c}\text { Varcha } \\
\mathrm{r}\end{array}$ & 8 & $\begin{array}{l}\text { Tgl } \\
\text { Inventaris }\end{array}$ \\
\hline 5 & Harga & $\begin{array}{c}\text { Varcha } \\
\mathrm{r}\end{array}$ & 12 & Harga \\
\hline
\end{tabular}

Tabel User

Tabel 4: User

\begin{tabular}{|c|l|c|c|c|}
\hline No & $\begin{array}{c}\text { Field } \\
\text { Name }\end{array}$ & Type & Size & Keterangan \\
\hline 1 & id_user & Varchar & 8 & Id User (PK) \\
\hline 2 & $\begin{array}{l}\text { User } \\
\text { Name }\end{array}$ & Varchar & 25 & User Name \\
\hline 3 & Password & Varchar & 25 & Password \\
\hline
\end{tabular}

\section{IMPLEMENTASI SISTEM}

\section{Halaman Home}

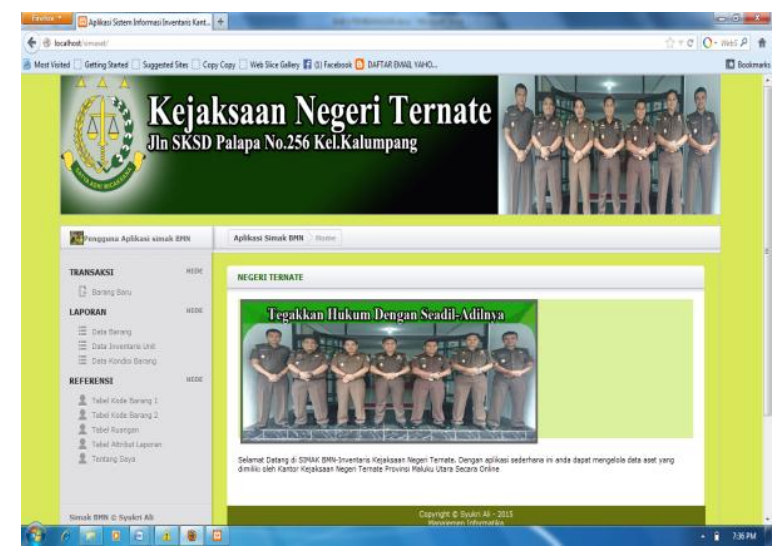

Gambar 6 : Menu Login Admin

\section{Input data Barang}

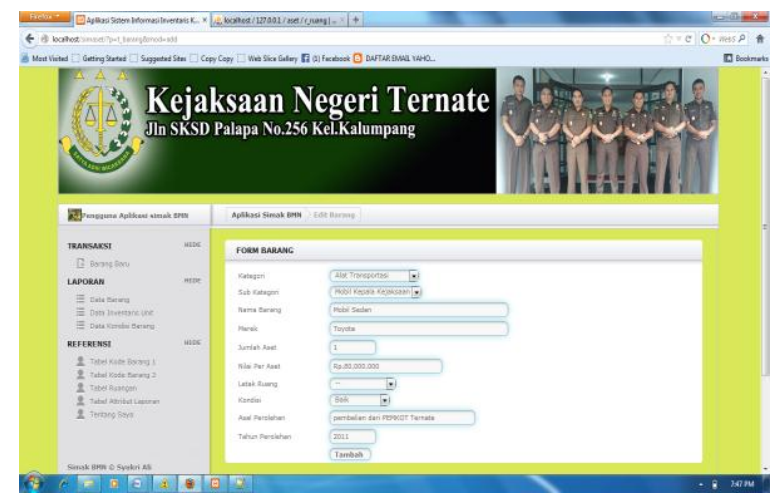

Gambar 7 : Menu input data barang

\section{Laporan Data Barang}

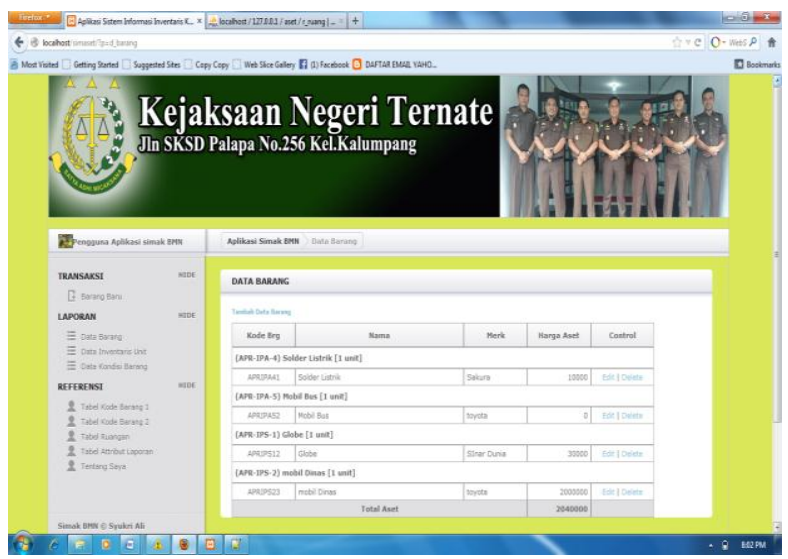

Gambar 8 : Menu laporan data barang

\section{Laporan Data Inventaris Unit}

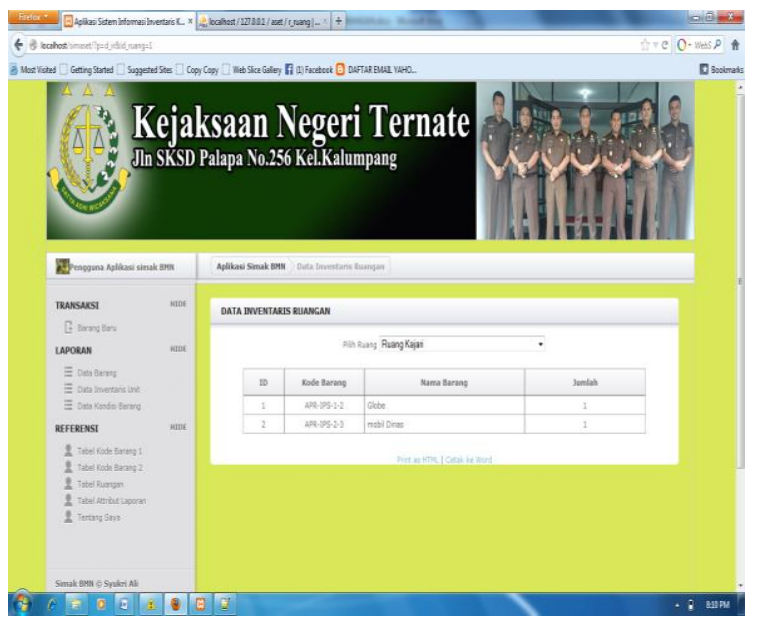

Gambar 9 : Menu data inventaris unit

\section{Laporan Data Kondisi Barang}

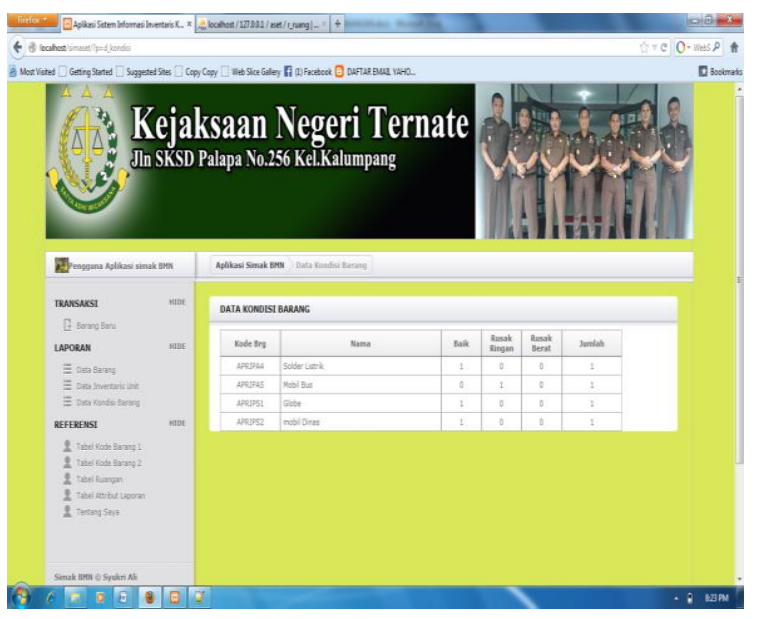

Gambar 10 : Menu data kondisi barang

\section{KESIMPULAN}

Setelah melakukan perancangan sampai pada tahap implementasi "Sistem 
Informasi Web Data Barang Inventaris Kantor Pada Kejaksaan Negeri Ternate dapat disimpulkan yaitu : 1. Dengan adanya sistem informasi ini dapat membantu pegawai di Kantor Kejaksaan Negeri Ternate dalam melaksanakan pendataan barang inventaris. Sistem informasi dapat membantu kinerja dan pelayanan pada Kejaksaan Negeri Kota Ternate dalam pengelolaan barang inventaris, 2. Sistem informasi ini menampilkan beberapa form yang dibutuhkan dalam penggunaannya seperti form penyaluran dan penerima. Form ini berfungsi sebagai media penyimpanan database yang langsung tersimpan dalam tabel yang sudah dibuat. Dengan adanya sistem informasi ini para pegawai juga dapat mengkontrol barang-barang inventaris menurut unitnya dan penggunaannya. Berdasarkan kseimpulan diatas maka diajukan saran sebagai berikut: 1. dapat menerapkan Sistem untuk mempermudah pegawai dalam mengelola barang invetaris yang ada pada Kejaksaan Negeri ternate. 2. dapat di jadikan sebagai acuan untuk menciptakan suatu aliran formasi yang baru secara sistematis dan terintegrasi yang dapat di susun menjadi sebuah sistem yang terpadu

\section{DAFTAR PUSTAKA}

Jogiyanto, 2005, Pengertian Sistem, Andi Offset.Yogyakarta.

Al Fatta Hanif.2007. Analisis dan Perancangan Sistem Informasi. Penerbit Andi.Yogyakarta

Kusrini, 2007, Pengertian Informasi, Unit Penerbit Percetakan STIM YKPN. Yogyakarta.

Nugroho, Bunafit. 2008. Latihan Membuat Aplikasi Web PHP dan MySQL dengan Dreamweaver.Gava Media, Yogyakarta
Akhmad Sholikhin, Berliana Kusuma Riasti (2013), Pembangunan Sistem Informasi Inventarisasi Sekolah Pada Dinas Pendidikan Kabupaten Rembang Berbasis Web, IJNS Indonesian Journal on Networking and Security, Vol 2 No 2 - Januari 2013, ijns.org, ISSN: 2302-5700

Fendra Sukmana, Sukadi, Sistem Informasi Pengolahan Data Barang Dan Service Komputer Pada Toko Sinar Terang Komputer Pacitan, IJNS Indonesian Journal on Networking and Security - Volume 3 No 4 Oktober 2014, ISSN: 2302-5700 (Print) 2354-6654 (Online) 